p-ISSN: $2338-4794$

e-ISSN: 2579-7476

Vol.8. No. 3 September-Desember 2020

\title{
PENGARUH PRICE EARNING RATIO, DEBT TO EQUITY RATIO, INFLASI, BI RATE, DAN KURS DOLAR TERHADAP HARGA SAHAM INDUSTRI KIMIA YANG LISTING DI BURSA EFEK INDONESIA
}

\author{
Budhi Suparningsih ${ }^{1)}$ \\ 1) Dosen Program Studi Manajemen FE UNKRIS \\ Email : budhiunkris@gmail.com \\ Ella Siti Chaeriah ${ }^{2)}$ \\ 2) Dosen Program Studi Manajemen FE UNKRIS \\ Alamat: Kampus UNKRIS, Jatiwaringin Jakarta Timur \\ Email : ellasiti.unkris@gmail.com
}

\begin{abstract}
The purpose of this study was to determine the effect of price earning ratio, debt to equity ratio, inflation, BI rate, and dollar exchange rate on stock prices. The population used in this study were chemical sector companies that had gone public in the Indonesian capital market until the end of 2018. The population in this study were 7 companies. Sampling was done by using the census method. Sample selection criteria, namely: a). Chemical sector companies listed on the Jakarta Stock Exchange before December 31, 2018. b). Remain listed on the Jakarta Stock Exchange until 31 December 2018. c). Providing periodic financial reports to the Jakarta Stock Exchange on December 31. Methods of data analysis using descriptive analysis and simple and multiple linear regression analysis. The results show that: (1) Simultaneously, price earning ratio, debt to equity ratio, inflation, BI rate, and dollar exchange rate on stock prices have a significant effect on stock prices (2) Partially price earning ratio, debt to equity ratio, inflation , BI rate, rupiah / dollar exchange rate do not have a significant effect on share prices. The conclusion is that in general investors who invest in chemical sector stocks are more shortterm investors who only pay attention to stock price fluctuations in the market.
\end{abstract}

Keyword: Price earning ratio, debt to equity ratio, inflasi, BI rate, kurs dollar, harga saham

\section{PENDAHULUAN}

Naik turunnya harga saham di pasar modal menjadi sebuah fenomena yang menarik untuk dibicarakan. Krisis ekonomi global yang terjadi pada tahun 2008 berdampak terhadap pasar modal. Kondisi seperti ini tentu akan mempengaruhi para investor untuk melakukan investasi di pasar modal khususnya saham, dan berdampak terhadap harga pasar saham di bursa. Seorang investor dalam melalukan aktivitas perdagangan saham di suatu negara harus memperhatikan situasi moneter dan pergerakan variabel ekonomi makro seperti inflasi, suku bunga, dan nilai tukar.

Di Indonesia perusahaan manufaktur merupakan perusahaan yang ikut terkena dampak dalam krisis ekonomi tersebut. Walaupun perusahaan manufaktur memiliki perkembangan yang begitu pesat. Hal ini dapat dilihat dari semakin bertambahnya perusahaan manufaktur di Indonesia yang terdaftar di Bursa Efek Indonesia. Oleh sebab itu bertambahnya perusahaan manufaktur tidak menutup kemungkinan perusahaan ini sangat dibutuhkan oleh masyarakat 
dan rencana kerja kedepannya akan menguntungkan perusahaan untuk di masa yang akan datang, akan tetapi persaingan pun semakin pesat. Adapun perusahaan manufaktur yang terdaftar di Bursa Efek Indonesia terdiri atas sektor industri dasar dan kimiau sektor aneka industri, dan sektor industri konsumsi. Sektor industri dasar dan kimia merupakan suatu sektor yang memiliki unsur dasar yang sering digunakan sehari-hari merupakan produk dari perusahaan industri dasar dan kimia, salah satunya yaitu sub sektor kimia.

"Harga saham adalah harga yang terbentuk melalui mekanisme permintaan dan penawaran di pasar modal. Apabila suatu saham mengalami kelebihan permintaan, maka harga saham cenderung naik. Sebaliknya, apabila kelebihan penawaran maka harga saham cenderung turun", menurut Sartono (2015). Berikut data harga saham perusahaan sub sektor kimia periode 2009 - 2018, yaitu:

Tabel 1. Harga Saham Perusahaan Sub Sektor Kimia Tahun 2009-2018

\begin{tabular}{|c|c|c|c|c|c|c|c|c|c|c|}
\hline \multicolumn{11}{|c|}{ Data Harga Saham Penutupan (Rupiah) } \\
\hline \multirow{2}{*}{$\begin{array}{l}\text { Kode } \\
\text { Emite }\end{array}$} & \multicolumn{10}{|c|}{ Tahun } \\
\hline & 2009 & 2010 & 2011 & 2012 & 2013 & 2014 & 2015 & 2016 & 2017 & 2018 \\
\hline BRPT & 226 & 159 & 519 & 431 & 288 & 208 & 148 & 508 & 1.549 & 1.557 \\
\hline DPNS & 274 & 252 & 264 & 400 & 305 & 273 & 248 & 256 & 256 & 266 \\
\hline EKAD & 328 & 342 & 407 & 294 & 300 & 328 & 341 & 405 & 491 & 492 \\
\hline INCI & 160 & 209 & 209 & 156 & 168 & 160 & 193 & 206 & 249 & 251 \\
\hline SRSN & 32 & 34 & 34 & 37 & 34 & 34 & 34 & 34 & 33 & 34 \\
\hline TPIA & 1.875 & 2.250 & 5.520 & 2.202 & 2.171 & 1.870 & 2.233 & 6.353 & 15.007 & 15.924 \\
\hline UNIC & 1.244 & 1.087 & 1.128 & 1.320 & 1.303 & 1.234 & 1.087 & 1.106 & 2.343 & 2.436 \\
\hline
\end{tabular}

Sumber: Data diolah dari Bursa Efek Indonesia, 2019

BRPT $=$ Barito Pasifik Tbk.

DPNS $=$ Duta Pertiwi Nusantara Tbk .

EKAD $=$ Ekadharma Internasional Tbk.

INCI = Intan Wijaya Internasional Tbk.

SRSN = Indo Acitama Tbk. / d.h Sarasa

Nugraha Tbk.

TPIA = Chandra Asri Petrochemical Tbk.

UNIC = Unggul Indah Cahaya Tbk.

Berdasarkan Tabel 1, menjelaskan tentang Harga Saham Perusahaan Sub Sektor Kimia periode tahun 2009 sampai dengan tahun 2018, yang mengalami fluktuasi dan tentunya akan berimbas pada pasar modal di Indonesia.

Secara normatif banyak faktor yang mempengaruhi harga saham, yaitu Faktor fundamental keuangan perusahaan seperti Price Earning Ratio (PER), Debt to Equity Ratio (DER) dan faktor fundamental makro seperti Inflasi, tingkat bunga khususnya BI Rate, Kurs Rupiah/Dollar, dan faktor-faktor lainnya.

Penelitian ini bertujuan untuk menganalisis secara bersama-sama price earning ratio (PER), Debt to Equity Ratio (DER) inflasi, BI rate, dan kurs rupiah/dollar, terhadap harga saham perusahaan sub sektor kimia.

\section{LANDASAN TEORI}

\section{Harga Saham}

Harga saham merupakan nilai saham yang ditentukan melalui 
permintaan dan penawaran yang terjadi di pasar modal. Menurut para ahli harga saham memiliki pengertian sebagai berikut:

"Harga saham terbentuk melalui mekanisme permintaan dan penawaran di pasar modal. Apabila suatu saham mengalami kelebihan permintaan, maka harga saham cenderung naik. Sebaliknya apabila kelebihan penawaran maka harga saham cenderung turun, menurut Sartono (2015)". "Harga suatu saham yang terjadi di pasar bursa pada saat tertentu yang di tentukan oleh pelaku pasar dan ditentukan oleh permintaan dan penawaran saham yang bersangkutan di pasar modal menurut Jogiyanto (2014)"

"Harga saham ditentukan menurut hukum permintaan dan penawaran atau kekuatan tawar- menawar. Makin banyak orang yang ingin membeli, maka harga saham tersebut cenderung bergerak naik. sebaliknya, semakin banyak orang yang ingin menjual saham maka saham terrsebut akan bergerak turun menurut Rusdin (2008)"

"Harga saham merupakan cerminan dan ekspektasi investor terhadap faktor faktor earning aliran kas dan tingkat return yang disyaratkan investor, yang mana ketiga faktor tersebut juga sangat berpengaruh oleh kinerja ekonomi makro menurut Tandelilin (2010)" "Harga saham menentukan kekayaan pemegang saham. Maksimalisasi kekayaan pemegang saham diterjemahkan menjadi maksimalkan harga saham perusahaan. Harga saham pada waktu tertentu akan bergantung pada arus kas yang diharapkan diterima dimasa depan oleh investor (rata-rata) jika investor membeli saham, menurut Brigham dan Houston (2010)"

Harga saham memiliki tiga jenis menurut Widoatmojo (2012), antara lain: 1). Harga normal; Harga yang tercantum dalam sertifikat, saham yang ditetapkan oleh emiten untuk menilai setiap lembar saham yang dikeluarkan. 2). Harga perdana; Harga yang didapatkan pada waktu harga saham tersebut dicatat di bursa efek. 3). Harga pasar; Harga jual dari investor yang satu dengan investor yang lain. Jika pasar sudah ditutup maka harga pasar adalah harga penutupannya (closing price).

Faktor yang mempengaruhi harga saham menurut Fahmi (2015) sebagai berikut: 1). Kondisi mikro dan makro ekonomi. 2). Kebijakan perusahaan dalam memutuskan untuk ekspansi. 3). Pergantian direksi secara tiba-tiba. 4). Direksi atau pihak komisaris terlibak tindak pidana dan kasusnya sudah masuk ke pengadilan. 5). Kinerja perusahan yang terus mengalami penurunan dalam setiap waktunya. 6). Risiko sistematis, yaitu suatu bentuk risiko yang terjadi secara menyeluruh dan telah ikut menyebabkan perusahaan ikut terlibat. 7). Efek dari psikologi pasar yang ternyata mampu menekan kondisi teknikal jual beli saham.

\section{Rasio Keuangan}

Menurut Fahmi (2015) rasio keuangan memiliki beberapa jenis sebagai berikut: 1). Rasio likuiditas; Adalah rasio yang menggambarkan kemampuan perusahaan untuk menyelesaikan kewajiban jangka pendeknya secara tepat waktu, rasio likuiditas memiliki bebrapa rasio antara lain: a). Current ratio. b). Quick ratio atau acid test ratio. c). Net working capital ratio. d). Cash flow liquidity ratio. 2). Rasio leverage atau solvabilitas; Merupakan rasio yang mengukur seberapa besar perusahaan dibiayai dengan utang. Penggunaan utang yang terlalu tinggi akan membahayakan perusahaan karena perusahaan akan masuk dalam kategori extreme leverage (utang ekstrem), yaitu perusahaan terjebak dalam tingkat utang yang tinggi dan sulit untuk melepaskan beban 
tersebut. Rasio leverage antara lain: a). Total debt to equity ratio. b). Total debt to total assets ratio. c). Time interest earned. d). Cash flow coverage. e). Long term debt to total capitalization. f). Fixed charge coverage. g). Cash flow adequancy.

\section{Price Earning Ratio (PER)}

Price Earning Ratio (PER) merupakan variabel independen dalam penelitian ini. PER yang di maksud dalam penelitian ini adalah rasio yang membandingkan antara harga pasar per lembar saham biasa yang beredar dengan laba per lembar saham. Price Earning ratio (PER) dapat dihitung dengan rumus Darmadji, (2011).

$$
\text { PER }=\frac{\text { Harga pasar saham biasa per-lembar }}{\text { Laba Per Lembar saham }}
$$

\section{Debt to equity ratio (DER)}

"Debt to equity ratio (DER) merupakan rasio antara total hutang dengan total modal sendiri. Ia mendifinisikan bahwa rasio ini menunjukan berapa bagian dari setiap rupiah modal sendiri yang dijadikan jaminan hutang menurut Munawir (2010)". "Debt to equity ratio merupakan rasio yang digunakan untuk mengukur tingkat leverage (penggunaan hutang) terhadap total shareholder's equity yang dimiliki perusahaan menurut Harahap (2012)"

"Debt to equity ratio merupakan salah satu rasio leverage atau solvabilitas. Rasio solvabilitas adalah rasio untuk mengetahui kemampuan perusahaan dalam membayar kewajiban jika perusahaan tersebut dilikuidasi. Rasio ini juga disebut dengan rasio pengukit (leverage) yaitu menilai batasan perusahaan dalam meminkam uang menurut darsono dan ashari (2010)". "Debt adalah ukuran yang dipakai dalam menganalisis laporan keuangan untuk memperlihatkan besarnya jaminan yang tersedia untuk kreditor menurut Siegel dan Shim dalam Fahmi (2015)"

"Debt to equity ratio merupakan rasio yang di gunakan untuk menilai hutang dengan ekuitas. Rasio ini dicari dengan cara membandingkan antara seluruh hutang, termasuk hutang lancar dengan seluruh ekuitas. Rasio ini digunakan untuk mengetahui jumlah dana yang disediakan peminjam (kreditor) dengan pemilik perusahaan. Dengan kata lain rasio ini berfungsi untuk mengetahui setiap rupiah modal sendiri yang dijadikan untuk jaminan hutang menurut Kasmir (2014)"

Berikut rumus untuk menghitung debt to equity ratio menurut Sartono (2015):

$$
D E R=\frac{\text { Total Debt }(\text { Total Hutang })}{\text { Total Equity }(\text { Total Ekuitas })}
$$

\section{Inflasi}

Menurut Sukirno (2012) "Inflasi adalah kecenderungan dari harga-harga untuk naik secara umum dan terus menerus. Akan tetapi bila kenaikan harga hanya dari satu atau dua barang saja tidak disebut inflasi, kecuali bila kenaikan tersebut meluas atau menyebabkan kenaikan sebagian besar dari harga barang-barang lain". Lebih lanjut 
menurut Pohan (2008) "Kenaikan hargaharga barang itu tidaklah harus dengan persentase yang sama. Inflasi merupakan kenaikan harga secara terus-menerus dan kenaikan harga yang terjadi pada seluruh kelompok barang dan jasa. Bahkan mungkin dapat terjadi kenaikan tersebut tidak bersamaan, yang penting kenaikan harga umum barang secara terus-menerus selama suatu periode tertentu". Sedangkan menurut Sukwiaty, et al, (2009) "Inflasi adalah suatu proses atau kejadian yang tidak berhubungan dengan tinggi rendahnya tingkat harga. Inflasi berlangsung apabila proses kenaikan harga berjalan secara terus-menerus serta saling mempengaruhi”.

"Kenaikan harga barang yang terjadi hanya sekali saja, meskipun dalam persentase yang cukup besar dan terusmenerus, bukanlah merupakan inflasi”, menurut Nopirin (2011). Kenaikan sejumlah bentuk barang yang hanya sementara dan sporadis tidak dapat dikatakan akan menyebabkan inflasi.

Inflasi tidak terjadi begitu saja, tapi disebabkan oleh berbagai faktor. Secara umum, penyebab inflasi adalah karena terjadinya kenaikan permintaan dan biaya produksi. Selengkapnya, berikut ini adalah beberapa penyebab inflasi: 1). Meningkatnya Permintaan (Demand Pull Inflation); Inflasi yang terjadi disebabkan karena peningkatan permintaan untuk jenis barang/ jasa tertentu. Dalam hal ini, peningkata permintaan jenis barang/ jasa tersebut terjadi secara agregat (agregat demand). Hal ini terjadi bisa disebabkan oleh beberapa faktor, diantaranya: a). Meningkatnya belanja pemerintah. b). Meningkatnya permintaan barang untuk diekspor. c). Meningkatnya permintaan barang untuk swasta. 2). Meningkatnya Biaya Produksi (Cost Pull Inflation); Inflasi yang terjadi karena meningkatnya biaya produksi. Adapun peningkatan biaya produksi disebabkan oleh kenaikan harga bahan-bahan baku, misalnya: a). Harga bahan bakar naik. b). Upah buruh naik. 3). Tingginya Peredaran Uang; Inflasi yang terjadi karena uang yang beredar di masyarakat lebih banyak dibanding yang dibutuhkan. Ketika jumlah barang tetap sedangkan uang yang beredar meningkat dua kali lipat, maka bisa terjadi kenaikan hargaharga hingga $100 \%$. Hal ini bisa terjadi ketika pemerintah menerapkan sistem anggaran defisit, dimana kekurangan anggaran tersebut diatasi dengan mencetak uang baru. Namun hal tersebut membuat jumlah uang yang beredar di masyarakat semakin bertambah dan mengakibatkan inflasi.

Inflasi dapat dibedakan menjadi 3 jenis, yaitu berdasarkan tingkat keparahan, penyebab, dan sumbernya. Berikut penjelasan selengkapnya: 1). Jenis Inflasi Berdasarkan Tingkat Keparahannya; Berdasarkan tingkat keparahannya, inflasi dibagi menjadi 4 yaitu : a). Inflasi Ringan, yaitu inflasi yang mudah untuk dikendalikan dan belum begitu menganggu perekonomian suatu negara. Terjadi kenaikan harga barang/jasa secara umum, yaitu di bawah $10 \%$ per tahun dan dapat dikendalikan. b). Inflasi Sedang, yaitu inflasi yang dapat menurunkan tingkat kesejahteraan masyarakat berpengahsilan tetap, namun belum membahayakan aktivitas perekonomian suatu negara. Inflasi ini berada di kisaran 10\% - 30\% per tahun. c). Inflasi Berat, yaitu inflasi yang mengakibatkan kekacauan perekonomian di suatu negara. Pada kondisi ini umumnya masyarakat lebih memilih menyimpan barng dan tidak mau menabung karena bunganya jauh lebih rendah ketimbang nilai inflasi. Inflasi ini berada di kisaran 30\% - 100\% per tahun. d). Inflasi Sangat Berat (Hyperinflation), yaitu inflasi yang telah mengacaukan perekonomian suatu negara dan sangat sulit untuk dikendalikan meskipun 
dilakukan kebijakan moneter dan fiskal. Inflasi ini berada di kisaran $100 \%$ ke atas per tahun. 2). Jenis Inflasi Berdasarkan Penyebabnya; Berdasarkan penyebabnya, inflasi dapat dibedakan menjadi 2, yaitu: a). Demand pull inflation, yaitu inflasi yang terjadi karena permintaan akan barang/ jasa lebih tinggi dari yang bisa dipenuhi oleh produsen. b). Cost push inflation, yaitu inflasi yang terjadi karena terjadi kenaikan biaya produksi sehingga harga penawaran barang naik. c). Bottle neck inflation, yaitu inflasi campuran yang disebabkan oleh faktor penawaran atau faktor permintaan. 3). Jenis Inflasi Berdasarkan Sumbernya; Berdasarkan sumbernya, inflasi dapat dibedakan menjadi 2, yaitu : a). Domestic inflation, yaitu inflasi yang bersumber dari dalam negeri. Inflasi ini terjadi karena jumlah uang di masyarakat lebih banyak daripada yang dibutuhkan. Inflasi jenis ini juga dapat terjadi ketika jumlah barang/ jasa tertentu berkurang sedangkan permintaan tetap sehingga harga-harga naik. b). Imported inflation, yaitu inflasi yang bersumber dari luar negeri. Inflasi ini terjadi pada negara yang melakukan perdagangan bebas dimana ada kenaikan harga di luar negeri. Contoh, Indonesia melakukan impor barang modal dari negara lain. Ternyata harga barang-barang modal di negara tersebut naik, kenaikan harga tersebut berdampak bagi Indonesia sehingga mengakibatkan inflasi.

\section{BI Rate}

Sebagaimana yang disebutkan dalam Inflation Targeting Framework bahwa BI Rate merupakan suku bunga acuan Bank Indonesia dan merupakan sinyal (Stance) dari kebijakan moneter Bank Indonesia. BI Rate adalah suku bunga instrumen sinyaling Bank Indonesia yang ditetapkan pada RDG (Rapat Dewan Gubernur) triwulanan untuk berlaku selama triwulan berjalan (satu triwulan), kecuali ditetapkan berbeda oleh RDG bulanan dalam triwulan yang sama. (Bank indonesia dalam Inflation Targeting Framework).

Pengertian tersebut terlihat jelas bahwa BI Rate berfungsi sebagai sinyal dari kebijakan moneter Bank Indonesia, dengan demikian dapat diambil kesimpulan bahwa respon kebijakan moneter dinyatakan dalam kenaikan, penurunan, atau tidak berubahnya BI Rate tersebut. "BI Rate adalah suku bunga dengan tenor satu bulan yang diumumkan oleh Bank Indonesia secara periodik untuk jangka waktu tertentu yang berfungsi sebagai sinyal (Stance) kebijakan moneter", menurut Siamat (2005).

Pengertian yang dikeluarkan oleh Dahlan Siamat tersebut dapat diambil kesimpulan bahwa BI Rate digunakan sebagai acuan dalam operasi moneter untuk mengarahkan agar rata-rata tertimbang suku bunga SBI-1 bulan hasil lelang OPT (Operasi Pasar Terbuka) berada disekitar BI Rate. Selanjutnya suku bunga SBI-1 bulan tersebut diharapkan akan mempengaruhi suku bunga pasar uang antar Bank (PUAB), suku bunga deposito dan kredit serta suku bunga jangka waktu yang lebih panjang.

\section{Mekanisme Penetapan BI Rate}

BI Rate ditetapkan oleh Dewan Gubernur Bank Indonesia dalam Rapat Dewan Gubernur (RDG) triwulanan setiap bulan Januari, April, Juli dan Oktober. Dalam kondisi tertentu, jika dipandang perlu, BI Rate dapat disesuaikan dalam RDG pada bulanbulan yang lain.

Pada dasarnya perubahan BI Rate menunjukkan penilaian Bank Indonesia terhadap prakiraan Inflasi ke depan dibandingkan dengan sasaran Inflasi yang ditetapkan. Pelaku pasar dan masyarakat akan mengamati penilaian Bank Indonesia tersebut melalui penguatan dan 
transparansi yang akan dilakukan, antara lain dalam Laporan Kebijakan Moneter yang disampaikan secara triwulanan dan press release bulanan. "Operasi Moneter dengan BI Rate dilakukan melalui lelang mingguan dengan mekanisme variabel rate tender dan multiple price allotments", menurut Siamat (2005).

Dengan demikian "Sinyal respon kebijakan moneter melalui BI Rate yang ditetapkan oleh Bank indonesia akan diperkuat melalui berbagai transaksi keuangan di pasar keuangan. Untuk meningkatkan efektifitas pengendalian likuiditas di pasar, Bank Indonesia akan memperkuat operasi moneter harian melalui instrumen Fine-Tune Operations (FTO) dengan underlying instrument SBI dan SUN", menurut Siamat (2005). Proses Penetapan respon kebijakan moneter dalam hal ini BI Rate: 1). Penetapan respon kebijakan moneter dilakukan dalam RDG triwulanan. 2). Respon kebijakan moneter diharapkan untuk periode satu triwulan kedepan. 3). Penetapan respon kebijakan moneter dilakukan dengan memperhatikan efek tunda (Lag) kebijakan moneter dalam mempengaruhi inflasi.

Dalam kondisi yang luar biasa, penetapan respon kebijakan moneter dapat dilakukan dalam RDG bulanan. Bank Indonesia dalam Inflation Targeting Framework, selain itu yang menjadi pertimbangan dalam penetapan respon kebijakan tersebut adalah : BI Rate merupakan respon bank sentral terhadap tekanan inflasi ke depan agar dapat tetap berada pada sasaran yang telah ditetapkan. Perubahan BI Rate dilakukan terutama jika deviasi proyeksi inflasi terhadap targetnya dipandang telah bersifat permanen dan konsisten dengan informasi dan indikator lainnya. BI Rate ditetapkan oleh Dewan Gubernur secara diskresi dengan mempertimbangkan rekomendasi BI Rate yang dihasilkan oleh fungsi reaksi kebijakan dalam model ekonomi untuk pencapaian sasaran inflasi. Berbagai informasi lainnya seperti leading indocators, expert opinion, asesmen faktor resiko dan ketidakpastian serta hasil-hasil riset ekonomi dan kebijakan moneter, Bank Indonesia dalam Inflation Targeting Framework.

\section{Kurs}

"Pertukaran suatu mata uang dengan mata uang lainya disebut transaksi valas", menurut Kuncoro (2007). Lebih lanjut "Harga suatu mata uang terhadap mata uang lainnya disebut kurs atau nilai tukar mata", menurut Salvatore (2005). "Kurs valuta asing juga dapat didefinisikan sebagai harga mata uang suatu negara dalam suatu negara dalam unit komoditas (seperti mata uang dapat diartikan sebagai perbandingan nilai mata uang). Kurs menunjukan harga suatu mata uang, jika dipertukarkan dengan mata uang lain. Sebagai contoh, nilai kurs Rp/USD sebesar 800, berarti bahwa untuk membeli 1 USD diperlukan Rp. 800" menurut Yulianti dan Prasetyo (2002).

"Penurunan kurs antara Rupiah dan USD (misalnya, dari Rp. 800/USD menjadi Rp. 900/USD) berarti Dolar menjadi lebih mahal dalam nilai Rupiah. Ini mencerminkan bahwa nilai Dolar naik karena jumlah Rupiah yang diperlukan untuk membeli Dolar meningkat. Dengan kata lain, Dolar mengalami apresiasi terhadap Rupiah. Dari sisi lain, Rupiah menjadi lebih murah dinilai asing mengalami apresiasi. Sebaliknya penurunan kurs mencerminkan terjadinya apresiasi mata uang domestik dan depresiasi mata uang asing", menurut Kuncoro (2007).

"Kebijakan kurs tukar dimana pemerintah suatu negara mengatur nilai tukar mata uangnya, maka diklasifikasikan sebagai kurs tetap (fixed exchange rate). Sedangkan jika besarnya nilai kurs tukar diserahkan kepada 
mekanisme pasar tanpa campur tangan pemerintah, diklasifikasikan sebagai sebagai sistem kurs mengambang", menurut Yulianti dan Prasetyo (2002).

"Suatu mata uang dikatakan konvertibel (convertible curency) apabila mata uang tersebut bisa dipertukarkan secara bebas dengan mata uang negara lain. Tidak adanya mata uang yang konvertibel akan menyulitkan perdagangan antar negara, karena masing-masing tidak akan mau menerima mata uang mitra dagangnya. Dalam keadaan seperti ini yang terjadi adalah perdagangan barter, yaitu menukar barang secara langsung, tetapi jika mata uang semua negara konvertibel maka perdagangan multinasional yang terjadi akan lebih efektif", menurut Yuliati dan Prasetyo (2002).

"Konvertibiltas penuh dari suatu mata uang yang dihambat, akan memunculkan pasar gelap dan beroperasi di luar kontrol pemerintah. Pada dasarnya pasar gelap adalah suatu pasar bebas yang berdampingan dengan pasar resmi dan menawarkan konversi penuh dalam mata uang lokal kendati ditambah premi yang cukup substansial di atas tarif resmi", menurut Kuncoro (2007).

Nilai tukar mata uang suatu negara memiliki korespondensi dengan tingkat inflasi. Dalam kondisi inflasi rendah, nilai mata uang cenderung mengalami apresiasi atau kenaikan karena uang yang beredar tidak banyak. Sedangkan kondisi sebaliknya terjadi ketika inflasi mencapai angka yang tinggi maka uang yang beredar banyak dan mengakibatkan depresiasi terhadap nilai mata uang. Harga barang mengalami kenaikan sehingga kemudian banyak barang impor yang masuk sebagai pesaing. Ketika negara melakukan impor, hal itu berarti negara sedang menambah angka permintaan terhadap mata uang asing dibandingkan permintaan terhadap mata uang domestik. Namun kenyataannya negara membutuhkan banyak mata uang asing yang tidak cukup hanya mengandalkan ekspor negara tersebut. Di sisi lain, mata uang negara tersebut mengalami penawaran tinggi yang tidak diimbangi dengan permintaan sehingga hal inilah yang kemudian menyebabkan nilai mata uang mengalami depresiasi.

"Nilai mata uang dan inflasi selanjutnya akan berdampak pada nilai suku bunga. Suku bunga adalah biaya yang dikeluarkan oleh kreditur atas pinjamannya sekaligus menjadi imbalan untuk pemberi dana utang. Dari sini bank sentral suatu negara akan memberlakukan suku bunga yang tinggi untuk menekan inflasi agar uang yang beredar dapat dikendalikan. Namun yang terpenting adalah dengan diberlakukannya suku bunga yang tinggi maka hal tersebut dapat menarik minat para investor serta modal asing sehingga kemudian nilai mata uang pun meningkat", menurut Thobarry (2009). Sehingga dapat dikatakan bahwa sebenarnya nilai mata uang sebanding dengan suku bunga.

Berdasarkan pendekatan hukum permintaan dan penawaran, maka harga dari valuta asing (misal US Dollar) akan menjadi lebih mahal dari nilai nominalnya apabila permintaan melebihi jumlah yang ditawarkan, atau jumlah permintaan tetap sementara penawaran berkurang. Sebaliknya, harga valuta asing akan menjadi lebih murah dari harga nominal atau harga berlakunya bila permintaan sedikit sementara penawaran banyak, atau permintaan semakin menurun meskipun jumlah penawaran tetap. Pada mekanisme pasar, nilai tukar terjadi pada saat tercapainya titik keseimbangan yaitu pada saat permintan sama dengan penawaran. Secara grafis keseimbangan harga melalui mekanisme pasar dapat dijelaskan sebagai berikut: 


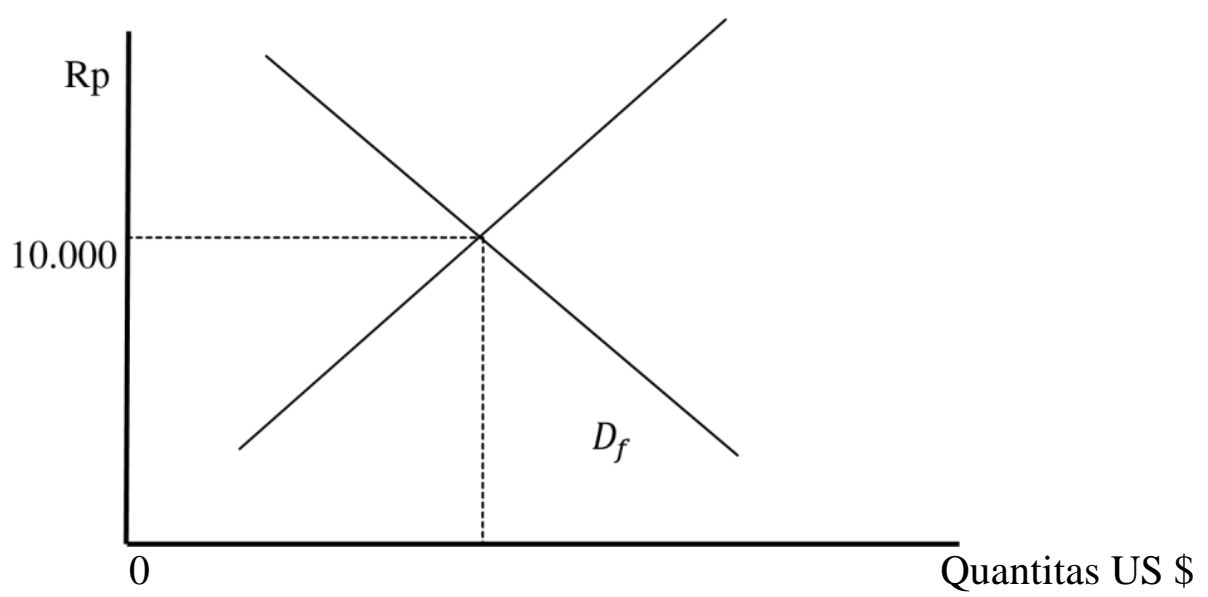

\section{Gambar 1: Keseimbangan Nilai Tukar Rupiah - Dollar}

Dalam gambar 1, diasumsikan sumbu vertikal adalah harga rupiah dari setiap unit US Dollar (bila harga bergerak keatas maka harga per unit dollar makin mahal atau dikatakan rupiah melemah/depresiasi) atau sebaliknya, sedangkan sumbu horizontal menunjukan jumlah US Dollar yang diminta atau ditawarkan. Kurva Sf adalah kurva penawaran valuta asing (US Dollar). Sedangkan kurva Df adalah kurva permintaan US dollar. Bila harga US Dollar semakin murah, maka permintaan terhadap jumlah US Dollar akan semakin meningkat, atau sebaliknya. Sekiranya dilihat dari sisi penawaran, harga US Dollar akan semakin mahal apabila jumlah US Dollar yang ditawarkan semakin meningkat, atau sebaliknya. Gambar diatas mengasumsikan yang berubah adalah harga dari US Dollar-nya, dan yang terjadi adalah pergerakan sepanjang kurva permintaan (movement along the demand curve). Kurva permintaan bergeser (shifting) bila yang berubah misalnya ada arus dana dari hasil ekspor, terjadinya keseimbangan awal pada saat nilai tukar rupiah adalah $\mathrm{Rp}$ $10.000,00$ per US Dollar.

\section{METODE PENELITIAN}

Dalam penelitian ini yang menjadi objek adalah perusahan-perusahaan yang bergerak di sektor kimia di Indonesia. Data yang digunakan dalam penelitian ini adalah data sekunder, yaitu data yang diperoleh dari listing BEI periode tahun 2009 sampai dengan periode tahun 2018. Populasi yang digunakan dalam penelitian ini adalah perusahaan sektor kimia (berdasarkan listing Bursa Efek Jakarta) yang telah go public di pasar modal Indonesia sampai akhir tahun 2018. Jumlah populasi dalam penelitian ini adalah sebanyak 7 perusahaan. Pengambilan sampel dilakukan dengan metode sensus. Sampel yang digunakan dalam penelitian ini didasarkan pada kriteria pemilihan sampel, yaitu : a). Perusahaan sektor kimia yang terdaftar di Bursa Efek Jakarta sebelum tanggal 31 Desember 2018. b). Tetap terdaftar di Bursa Efek Jakarta sampai 31 Desember 2018. c). Memberikan laporan keuangan secara periodik kepada Bursa Efek Jakarta pada tanggal 31 Desember. Metode analisis data dengan menggunakan analisis deskriptif dan analisis regresi linear sederhana maupun berganda. (Sugiyono, 2017). 


\section{HASIL PENELITIAN DAN PEMBAHASAN}

\section{Hasil Uji Asumsi}

Uji asumsi bertujuan untuk mengetahui apakah model regresi yang diperoleh dapat menghasilkan estimator yang baik, yaitu :

\section{Uji Normalitas}

Uji normalitas digunakan untuk menguji apakah dalam model regresi variabel pengganggu dan residual berdistribusi normal atau tidak. Uji normalitas dapat dilakukan dengan banyak cara, diantaranya yaitu dengan Uji sampel (KS) Kolmogorov-Smirnov yaitu apabila A symp. Sig $>$ taraf Signifikan $(\alpha)$ atau data normal bila nilai sig $(p)>0,05$ dan data tidak normal bila nilai sig (p) < 0,05. Uji normalitas dengan melihat angka signifikan dari Kolmogorov-Smirnov pada data residual. Hasil uji Kolmogorov-Smirnov menunjukkan bahwa nilai Asymp. Sig. (2-tailed) sebesar 0,808 yang berarti lebih besar dari $0,05(0,808>0,05)$, Sehingga dapat diartikan bahwa nilai residual berdistribusi normal dan menandakan bahwa data layak digunakan dalam penelitian.

\section{Uji Multikolinearitas}

Uji multikolinearitas digunakan untuk menguji apakah di dalam persamaan regresi terdapat korelasi antara varian variabelnya. Di dalam persamaan regresi tidak boleh terjadi multikolinearitas, maksudnya tidak boleh ada korelasi atau hubungan yang sempurna antara variabel bebas yang membentuk persamaan tersebut. Uji multikolinearitas dilakukan dengan melihat nilai Variance Inflation Factor (VIF).
1. Jika nilai tolerance $>0,10$ dan nilai VIF < 10, maka dapat disimpulkan bahwa tidak ada multikolinearitas antar variabel bebas dalam model regresi.

2. Jika nilai tolerance $<0,10$ dan nilai VIF > 10, maka dapat disimpulkan bahwa ada multikolinearitas antar variabel bebas dalam model regresi.

Dari perhitungan uji multikolinearitas didapat nilai tolerance masing-masing variabel: 1). Nilai tolerance PER $0,481>0,10 ; 2)$. Nilai tolerance DER $0,8224>0,10 ; 3)$. Nilai tolerance Inflasi $0,502>0,10 ; 4)$. Nilai tolerance BI Rate 0,529 > 0,10; dan 5). Nilai tolerance Kurs Rupiah 0,481> 0,10 .

Sedangkan dari hasil nilai VIF masing-masing variable diperoleh: 1). VIF PER 2,079 < 10; 2). VIF DER 4,469 $<$ 10; 3). VIF Inflasi 1,993 < 10; 4). VIF BI Rate 1,891 < 10; dan 5). VIF Kurs Rupiah 2,079 $<10$

Hasil pengujian tolerance menunjukkan tidak ada variabel bebas yang memiliki nilai tolerance $>0,10$ dari nilai Variance Inflation Factor (VIF) < 10. Sehingga dapat disimpulkan bahwa tidak terdapat gejala multikolinearitas.

\section{Uji Heteroskedastisitas}

Uji heteroskedastisitas digunakan untuk mengetahui apakah dalam model regresi terjadi ketidaksamaan varian dari residual satu pengamatan ke pengamatanan. Suatu model dapat dikatakan tidak mengalami gejala heteroskedastisitas jika hasil nilai probabilitasnya memiliki nilai signifikansi > nilai alpha-nya $(0,05)$, maka model tidak mengalami heteroskedastisitas. Dari hasil uji heteroskedastisitas dapat disimpulkan bahwa probabilitas atau taraf signifikan PER 1,000, DER 1,000, Inflasi bernilai 1,000, BI Rate bernilai 1,000 dan Kurs Rupiah bernilai 1,000 sehingga dapat 
dipastikan model tersebut tidak mengalami gejala heteroskedastisitas, dengan kata lain korelasi PER, DER, Inflasi, BI Rate, dan Kurs Rupiah dengan nilai residualnya menghasilkan nilai yang lebih tinggi dari alphanya. Karena suatu model dapat dikatakan mengalami gejala heterokedastitas jika nilai probabilitasnya atau nilai tarif signifikannya $<0,05$.

\section{Uji Autokorelasi}

Uji autokorelasi digunakan untuk mengetahui ada tidaknya korelasi antar anggota serangkaian data yang di observasi dan di analisis menurut ruang atau menurut waktu, cross section atau time-series. Beberapa cara untuk mendeteksi ada tidaknya autokorelasi yaitu dapat diketahui dengan metode grafik, metode Durbin-Waston, metode runtest, dan uji statistik non parametrik.
Dalam penelitian ini akan digunakan uji autokorelasi dengan menggunakan metode Durbin-Waston, hasil pengelolahan dapat disimpulkan bahwa suatu model dapat dinyatakan tidak terjadi gejala autokorelasi, jika probabilitas nilai Durbin-Waston > 0,05. Pada tabel di atas probabilitas nilai Durbin-Waston adalah 1,575 >0,05, maka dapat di pastikan bahwa metode tersebut tidak mengalami gejala autokorelasi.

\section{Analisis Hasil Penelitian}

\section{Analisis Regresi Linear Berganda}

Untuk mengetahui sejauh mana pengaruh secara simultan price earning ratio (PER), debt to equity ratio (DER), inflasi, BI rate, dan kurs rupiah/dollar terhadap harga saham.

Tabel. 2 Pengaruh Price Earning Ratio, Debt to Equity Ratio, Inflasi, BI Rate, dan Kurs Rupiah/Dollar Terhadap Harga Saham

\begin{tabular}{lccccc}
\hline \multirow{2}{*}{ Variabel } & \multirow{5}{*}{ R Square } & Konstanta & $\begin{array}{c}\text { Koef. } \\
\text { Regresi }\end{array}$ & Sig. & $\boldsymbol{\alpha}$ \\
\cline { 2 - 6 } & \multirow{2}{*}{0.910} & 8826.481 & -99.867 & 0.267 & 0.05 \\
PER & & & -5981.264 & 0.123 & 0.05 \\
DER & & & 540.373 & 0.663 & \\
Inflasi & & & -599.952 & 0.037 & \\
BI_Rate & & & 0.039 & 0.700 & \\
Kurs_Rupiah & & & &
\end{tabular}

\section{Pengujian Signifikansi}

F hitung $>$ F tabel $=8.057>6.256$

Keterangan: Variabel Harga_Saham

Sumber: data diolah 2019

Berdasarkan Tabel 2, dapat diketahui bahwa price earning ratio (PER), debt to equity ratio (DER), inflasi, $\mathrm{BI}$ rate dan kurs rupiah/dollar secara simultan memiliki pengaruhi signifikan terhadap harga saham Perusahaan Sub Sektor Kimia. Dengan poin nilai yang diperoleh sebesar $0,015^{\text {a }}$ lebih kecil dari $\alpha$ $=0,05(0,033<0,05)$. Atau dapat juga diketahui dengan melihat nilai $\mathrm{F}$ hitung sebesar 8,057 yang lebih besar dari $\mathrm{F}$ tabel 6,256 $(8,057>6,256)$.

Secara simultan price earning ratio (PER), debt to equity ratio (DER), inflasi, BI rate, dan kurs rupiah mampu memberi kontibusi sebesar 0,910 atau 91,0\% terhadap harga saham perusahaanperusahaan sektor kimia, sedangkan sisanya sebesar $0,9 \%$ dipengaruhi oleh 
variabel-variabel lainnya yang tidak diteliti dalam penilitian ini.

Persamaan regresi linear berganda sebagai berikut :

$$
\begin{gathered}
\mathrm{Y}=8826.481-99.867 \text { PER }-5981.264 \text { DER }+540.373 \text { Inflasi } \\
-\quad \text { 599.952 BI Rate }+ \text { 0.039 Kurs Rupiah }
\end{gathered}
$$

Price earning ratio memiliki nilai koefisien regresi sebesar -99.867. Hal ini menggambarkan bahwa jika terjadi kenaikan price earning ratio sebesar 1 point atau $1 \%$. Maka harga saham Perusahaan Sub Sektor Kimia mengalami kenaikan sebesar -99.867 dengan asumsi bahwa price earning ratio bernilai negatif artinya terdapat hubungan negatif antara price earning ratio dengan harga saham Perusahaan Sub Sektor Kimia.

Debt to equity ratio memiliki nilai koefisien regresi sebesar -5981.264. Hal ini menggambarkan bahwa jika terjadi kenaikan debt to equity ratio sebesar 1 point atau $1 \%$. Maka harga saham Perusahaan Sub Sektor Kimia mengalami kenaikan sebesar -5981.264 dengan asumsi bahwa debt to equity ratio bernilai negatif artinya terdapat hubungan negatif antara debt to equity ratio dengan harga saham Perusahaan Sub Sektor Kimia.

Inflasi memiliki nilai koefisien regresi sebesar 540.373. Hal ini menggambarkan bahwa jika terjadi kenaikan inflasi sebesar 1 point atau $1 \%$. Maka harga saham Perusahaan Sub Sektor Kimia akan meningkat sebesar 540.373 dengan asumsi bahwa Inflasi bernilai positif artinya terdapat hubungan positif antara inflasi dengan harga saham Perusahaan Sub Sektor Kimia.

$\mathrm{BI}$ rate memiliki nilai koefisien regresi sebesar -599.925. Hal ini menggambarkan bahwa jika terjadi kenaikan BI rate sebesar 1 point atau $1 \%$. Maka harga saham Perusahaan Sub Sektor Kimia akan meningkat sebesar 599.925 dengan asumsi bahwa BI rate bernilai negatif artinya terdapat hubungan negatif antara BI rate dengan harga saham Perusahaan Sub Sektor Kimia.

Kurs rupiah memiliki nilai koefisien regresi sebesar 0.039. Hal ini menggambarkan bahwa jika terjadi kenaikan kurs rupiah sebesar 1 point atau 1\%. Maka harga saham Perusahaan Sub Sektor Kimia akan meningkat sebesar 0.039 dengan asumsi bahwa kurs rupiah bernilai positif artinya terdapat hubungan positif antara kurs rupiah dengan harga saham Perusahaan Sub Sektor Kimia.

\section{Analisis Regresi Linear Sederhana}

Untuk mengetahui pengaruh secara parsial masing-masing variabel bebas terhadap Harga Saham, maka dilakukan uji statistik secara parsial dengan hasil sebagai berikut:

Tabel. 3 Pengaruh Price Earning Ratio Terhadap Harga Saham

\begin{tabular}{lccccc}
\hline \multirow{2}{*}{ Variabel } & R Square & Konstanta & $\begin{array}{c}\text { Koef. } \\
\text { Regresi }\end{array}$ & Sig. & $\boldsymbol{\alpha}$ \\
\cline { 2 - 6 } & 0.225 & -563.164 & 169.344 & 0.166 & 0.05 \\
\hline Price Earning Ratio & & & & & \\
\hline Pengujian Signifikansi & & & & & \\
\hline
\end{tabular}


$\mathrm{t}$ hitung $>\mathrm{t}$ tabel $=1.522>2.306$

Keterangan: Variabel Harga_Saham

Sumber: data diolah 2019

Berdasarkan Tabel 3, nilai $\mathrm{R}$ Square sebesar 0.225, sehingga dapat diartikan bahwa kontribusi price earning ratio kepada harga saham Perusahaan Sub Sektor Kimia sebesar 22,5\%, sedangkan sisanya sebesar $77,5 \%$ disumbangkan variabel lain, seperti debt to equity ratio, inflasi, BI rate, dan kurs rupiah/dollar.

Persamaan regresi $\mathrm{Y}=-563.164+$ 169.344 PER

Hasil penelitian menunjukkan bahwa koefisien price earning ratio berpengaruh positif terhadap harga saham
Perusahaan Sub Sektor Kimia. Nilai koefisien price earning ratio sebesar 169.344, hal ini menggambarkan bahwa jika terjadi kenaikan price earning ratio sebesar 1 persen, maka harga saham Perusahaan Sub Sektor Kimia mengalami kenaikan sebesar 169.344. Hasil t hitung price earning ratio sebesar 1,522. Jika $\mathrm{t}$ hitung 1,522 < t tabel 2,306, maka ho terima dan ha tolak, artinya price earning ratio secara parsial tidak berpengaruh signifikan terhadap harga saham Perusahaan Sub Sektor Kimia.

Tabel. 4 Pengaruh Debt to Equity Ratio Terhadap Harga Saham

\begin{tabular}{lccccc}
\hline \multirow{2}{*}{ Variabel } & R Square & Konstanta & $\begin{array}{c}\text { Koef. } \\
\text { Regresi }\end{array}$ & Sig. & $\boldsymbol{\alpha}$ \\
\hline Debt to Equity Ratio & 0.664 & 5783.317 & -7857.050 & 0.004 & 0.05 \\
\hline Pengujian Signifikansi & & & & & \\
\hline t hitung $>$ t tabel $=-3.976>2.306$ & & & & & \\
\hline
\end{tabular}

Keterangan: Variabel Harga_Saham

Sumber: data diolah 2019

Berdasarkan Tabel 4, nilai RSquare sebesar 0.664, sehingga dapat diartikan bahwa kontribusi debt to equity ratio kepada harga saham Perusahaan Sub Sektor Kimia sebesar 66,4\%, sedangkan sisanya sebesar $33,6 \%$ disumbangkan variabel lain, seperti price earning ratio, inflasi, BI rate, dan kurs rupiah/dollar.

Persamaan regresi $\mathrm{Y}=5783.317$ 7857.050 DER

Hasil penelitian menunjukkan bahwa koefisien debt to equity ratio berpengaruh negatif terhadap harga saham Perusahaan Sub Sektor Kimia. Nilai koefisien debt to equity ratio sebesar -5783.317, hal ini menggambarkan bahwa jika terjadi kenaikan debt to equity ratio sebesar 1 persen, maka harga saham Perusahaan Sub Sektor Kimia mengalami penurunan sebesar -5783.317. Hasil t hitung price earning ratio sebesar $-3,976$. Jika t hitung $-3,976<\mathrm{t}$ tabel 2,306, maka ho terima dan ha tolak, artinya debt to equity ratio secara parsial tidak berpengaruh signifikan terhadap harga saham Perusahaan Sub Sektor Kimia. 
Tabel. 5 Pengaruh Inflasi Terhadap Harga Saham

\begin{tabular}{lccccc}
\hline \multirow{2}{*}{ Variabel } & R Square & Konstanta & $\begin{array}{c}\text { Koef. } \\
\text { Regresi }\end{array}$ & Sig. & $\boldsymbol{\alpha}$ \\
\cline { 2 - 6 } & 0.168 & 2053.131 & -2223.656 & 0.240 & 0.0 \\
Inflasi & & & & & 5 \\
\hline
\end{tabular}

Pengujian Signifikansi

$\mathrm{t}$ hitung $>\mathrm{t}$ tabel $=-1.270>2.306$

Keterangan: Variabel Harga_Saham

Sumber: data diolah 2019

Berdasarkan Tabel 5, nilai RSquare sebesar 0.168, sehingga dapat diartikan bahwa kontribusi inflasi kepada harga saham Perusahaan Sub Sektor Kimia sebesar $16,8 \%$, sedangkan sisanya sebesar $83,2 \%$ disumbangkan variabel lain, seperti price earning ratio, debt to equity ratio, $\mathrm{BI}$ rate, dan kurs rupiah/dollar.

Persamaan regresi $\mathrm{Y}=2053.131$ 2223.656 Inflasi

Hasil penelitian menunjukkan bahwa koefisien inflasi berpengaruh negatif terhadap harga saham Perusahaan Sub Sektor Kimia. Nilai koefisien inflasi sebesar -2223.656, hal ini menggambarkan bahwa jika terjadi kenaikan inflasi sebesar 1 persen, maka harga saham Perusahaan Sub Sektor Kimia mengalami penurunan sebesar 2223.656. Hasil t hitung inflasi sebesar $-1,270$. Jika $t$ hitung $-1,270<\mathrm{t}$ tabel 2,306, maka ho terima dan ha tolak, artinya inflasi secara parsial tidak berpengaruh signifikan terhadap harga saham Perusahaan Sub Sektor Kimia.

Tabel. 6 Pengaruh BI Rate Terhadap Harga Saham

\begin{tabular}{lccccc}
\hline \multirow{2}{*}{ Variabel } & R Square & Konstanta & $\begin{array}{c}\text { Koef. } \\
\text { Regresi }\end{array}$ & Sig. & $\boldsymbol{\alpha}$ \\
\hline BI Rate & 0.683 & 6068.832 & -776.862 & 0.003 & 0.05 \\
\hline Pengujian Signifikansi & & & & & \\
\hline $\mathrm{t}$ hitung $>\mathrm{t}$ tabel $=-4.148>2.306$ & & & & & \\
\hline
\end{tabular}

Keterangan: Variabel Harga_Saham

Sumber: data diolah 2019

Berdasarkan Tabel 6, nilai $\mathrm{R}$ Square sebesar 0.683, sehingga dapat diartikan bahwa kontribusi BI rate kepada harga saham Perusahaan Sub Sektor Kimia sebesar 68,3\%, sedangkan sisanya sebesar $31,7 \%$ disumbangkan variabel lain, seperti price earning ratio, debt to equity ratio, inflasi, dan kurs rupiah/dollar. 
Persamaan regresi $\mathrm{Y}=6068.832$ $776.862 \mathrm{BI}$ rate

Hasil penelitian menunjukkan bahwa koefisien BI rate berpengaruh negatif terhadap harga saham Perusahaan Sub Sektor Kimia. Nilai koefisien inflasi sebesar -776.862, hal ini menggambarkan bahwa jika terjadi kenaikan BI rate sebesar 1 persen, maka harga saham Perusahaan Sub Sektor Kimia mengalami penurunan sebesar -776.862. Hasil $t$ hitung inflasi sebesar $-4,148$. Jika t hitung $-4,148<\mathrm{t}$ tabel 2,306, maka ho terima dan ha tolak, artinya BI rate secara parsial tidak berpengaruh signifikan terhadap harga saham Perusahaan Sub Sektor Kimia.

Tabel. 7 Pengaruh Kurs Rupiah/Dollar Terhadap Harga Saham

\begin{tabular}{lccccc}
\hline \multirow{2}{*}{ Variabel } & R Square & Konstanta & $\begin{array}{c}\text { Koef. } \\
\text { Regresi }\end{array}$ & Sig. & $\boldsymbol{\alpha}$ \\
\hline Kurs Rupiah/Dollar & 0.314 & -1634.457 & 0.245 & 0.092 & 0.05 \\
\hline Pengujian Signifikansi & & & & & \\
\hline t hitung $>$ t tabel $=1.913>2.306$ & & & & & \\
\hline
\end{tabular}

Keterangan: Variabel Harga_Saham

Sumber: data diolah 2019

Berdasarkan Tabel 7, nilai RSquare sebesar 0.314, sehingga dapat diartikan bahwa kontribusi Kurs Rupiah/Dollar kepada harga saham Perusahaan Sub Sektor Kimia sebesar $31,7 \%$, sedangkan sisanya sebesar $68,3 \%$ disumbangkan variabel lain, seperti price earning ratio, debt to equity ratio, inflasi, dan BI rate.

Persamaan regresi $\mathrm{Y}=-1634.457+0.245$ Kurs Rupiah/Dollar

Hasil penelitian menunjukkan bahwa koefisien Kurs Rupiah/Dollar berpengaruh positif terhadap harga saham Perusahaan Sub Sektor Kimia. Nilai koefisien kurs rupiah/dollar sebesar 0.245 , hal ini menggambarkan bahwa jika terjadi kenaikan kurs rupiah/dollar sebesar 1 rupiah/dollar, maka harga saham Perusahaan Sub Sektor Kimia mengalami kenaikan sebesar 0.245. Hasil $\mathrm{t}$ hitung inflasi sebesar 1,913. Jika $\mathrm{t}$ hitung $1,913<\mathrm{t}$ tabel 2,306, maka ho terima dan ha tolak, artinya kurs rupiah/dollar secara parsial tidak berpengaruh signifikan terhadap harga saham Perusahaan Sub Sektor Kimia.

\section{Pembahasan}

Pengaruh Price Earning Ratio, Debt to Equity Ratio, Inflasi, BI Rate, dan Kurs Rupiah/Dollar Terhadap Harga Saham Hasil penelitian menunjukkan bahwa price earning ratio, debt to equity ratio, inflasi, BI rate, dan kurs rupiah/dollar secara bersama-sama berpengaruh terhadap harga saham Perusahaan Sub Sektor Kimia. Hal ini dapat dilihat dalam investasi saham di pasar modal seorang investor yang membutuhkan beberapa informasi untuk membantunya dalam melakukan pengambilan keputusan. Pasar modal yang efisien merupakan pasar yang mencerminkan semua informasi yang relevan terhadap harga sekuritas saham. Informasi relevan tersebut salah satunya dengan melihat kondisi mikro dan makro 
ekonomi yaitu dalam penelitian ini adalah inflasi, BI rate, dan kurs rupiah/dollar. Dengan melihat kondisi mikro dan makro ekonomi tersebut, maka dapat membantu investor untuk melakukan pengambilan keputusan yaitu pembelian atau penjualan saham. Karena harga saham merupakan hal yang penting bagi investor yang nantinya digunakan investor untuk memprediksi naik turunnya harga saham dan nantinya menghasilkan return. Hasil penelitian ini sejalan dengan penelitian yang dilakukan oleh Ginting, Topowijoyo, dan Sulasmiyati (2016) yang menyatakan bahwa price earning ratio, debt to equity ratio, inflasi, BI rate, dan Kurs Rupiah/Dollar berpengaruh terhadap Terhadap harga saham.

\section{Pengaruh Price Earning Ratio Terhadap Harga Saham}

Secara umum price earning ratio merupakan indikator yang digunakan untuk menghitug tingkat pengembalian modal yang diinvestasikan pada suatu saham. Hal ini dapat dilihat dari kemampuan yang kecil price earning ratio dalam memprediksi harga saham sangat tidak dimungkinkan karena sifat dan pola price earning ratio yang dilakukan oleh perusahaan sangat tidak tepat sehingga ada sebagian aktiva yang bekerja atau digunakan secara tidak efisien sehingga harga saham yang diperoleh tidak maksimal. Selain itu pendapatan yang dihasilkan oleh modal yang berasal dari hutang tidak dapat digunakan untuk menutup besarnya biaya modal dan kekurangan tersebut harus ditutup oleh sebagian pendapatan yang berasal dari pemegang saham. Dengan mengetahui besaran price earning ratio tersebut, calon investor potensial dapat mengetahui apakah harga sebuah saham tergolong wajar atau tidak sesuai dengan kondisi saat ini dan bukan berdasarkan pada perkiraan di masa mendatang. Price earning ratio menunjukkan penilaian investor terhadap harga saham perusahaan terutama terkait dengan berapa dana yang akan diinvestasikan oleh investor untuk setiap pendapatan yang dilaporkan oleh perusahaan. Price earning ratio yang tinggi akan meningkatkan penilaian investor terhadap saham perusahaan. Penilaian yang tinggi ini akan meningkatkan harga saham. Hasil penelitian ini tidak sejalan dengan penelitian yang dilakukan oleh Ratih, et $a l$, (2013) yang menyatakan bahwa price earning ratio tidak berpengaruh terhadap harga saham.

\section{Pengaruh Debt to Equity Ratio Terhadap Harga Saham}

Secara umum debt to equity ratio merupakan salah satu rasio keuangan yang mengukur seberapa besar kemampuan perusahaan melunasi utang dengan modal yang dimiliki. Hal ini dapat dilihat semakin tinggi nilai debt to equity ratio maka akan diikuti semakin tinggi tingkat harga saham perusahaan yang bersangkutan. Harga saham perusahaan umumnya dapat menjadi tolak ukur atau memonitor perusahaan dalam penelitian ini debt to equity ratio mempengaruhi tingkat harga saham perusahaan yang bersangkutan. Hal ini disebabkan karena tingkat debt to equity ratio tidak berpengaruhi secara langsung sehingga tidak langsung akan semakin meningkatkan harga saham. debt to equity ratio menyatakan bahwa monitoring yang dilakukan oleh investor perusahaan tentunya akan menjamin kemakmuran untuk pemegang saham, pengaruh debt to equity ratio sebagai agen pengawas ditekan melalui debt to equity ratio mereka yang cukup besar dalam pasar modal. Tingkat debt to equity ratio yang tinggi akan menimbulkan usaha pengawasan yang lebih besar oleh pihak investor perusahaan sehingga dapat mengurangi perilaku oportunistik manajer dan debt to 
equity ratio. Debt to equity ratio yang tinggi menunjukkan bahwa perusahaan sangat bergantung pada pihak luar dalam mendanai kegiatan sehingga beban perusahaan juga akan meningkat. Hasil penelitian ini sejalan dengan penelitian yang dilakukan oleh Ramadhani dan Pustikaningsih, (2017) yang menyatakan bahwa debt to equity ratio tidak berpengaruh terhadap harga saham.

\section{Pengaruh Inflasi Terhadap Harga Saham}

Secara umum Inflasi merupakan indikator untuk melihat perubahan atau terjadinya proses kenaikan harga yang terjadi secara terus-menerus. Semakin besar nilai inflasi merupakan bukti bahwa nilai mata uang menjadi semakin kecil dan roda ekonomi menjadi melambat. Perusahaan - perusahaan yang dapat memprediksi range analisis dengan cermat maka akan menjadi faktor penentu perusahaan tersebut dapat memiliki status kesetabilan dan perkembangan kedepan. Tapi inflasi tidak berdampak sehebat keperusahaan perusahaan non pokok. Sedangkan sektor kimia merupakan kategori perusahaan yang menghasilkan kebutuhan pokok seperti dibidang makanan, kesehatan hingga atribut pendukung produksi seperti pupuk. Hal ini dapat dilihat dari Inflasi yang terjadi sama sekali tidak mempengaruhi terhadap perubahan harga saham. Kondisi ini dapat dipahami, karena Inflasi yang terjadi pada periode yang diteliti relatif stabil. Walaupun Inflasi trennya menurun, dan Harga Saham trennya naik, tetapi penurunan Inflasi tidak mempengaruhi Harga Saham secara signifikan. Investor dan trader masih mempercayai bahwa keadaan Inflasi tidak akan terlalu berpengaruh terhadap perubahan Harga Saham karena kondisi inflasi yang terjadi masih dalam batas wajar. Hasil penelitian ini sejalan dengan penelitian yang dilakukan oleh Indriyani dan Armereo
(2016) yang menyatakan bahwa inflasi tidak berpengaruh terhadap harga saham.

\section{Pengaruh BI Rate Terhadap Harga Saham}

Bursa saham merupakan pasar yang menjual reputasi perushaan-perusahaan yang memiliki tingkat kelas. Kesetabilan perusahaan merupakan indikator utama. Untuk itu ada istilah perusahaan Blue Chip yang merupakan perusahaanperushaan yang memiliki kestabilan dalam perjalanannya sehingga presentase naik dan turunnya tidak berfluktuasi secara extrim dalam hal value serta fluktuasinya tidak terus terjadi setiap waktu. Dalam hal ini tentu tentu ada suatu bentuk badan yang menjadi acuan sebagai pengawas sebagai acuan rating. Dalam hal ini BI merupakan muara dari data dan informasi kesetabilan keuangan perusahaan-perusahaan yang terdaftar di bursa saham. Hal ini dapat dilihat dari pengaruh BI Rate menjadi patokan bagi investor untuk mengestimasi apakah nantinya suku bunga bank seperti suku bunga deposito atau suku bunga kredit akan naik atau turun. Berdasarkan kaitannya dengan investasi, jika suku bunga BI Rate naik maka return investasi yang terkait dengan suku bunga seperti deposito akan naik juga. Kondisi seperti ini akan menarik minat investor yang sebelumnya berinvestasi di saham untuk memindahkan dananya dari saham ke dalam deposito. Jika sebagian besar investor melakukan tindakan yang sama maka banyak investor yang akan menjual saham untuk berinvestasi dalam bentuk deposito. Jika banyak pihak yang menjual saham, maka harga saham akan turun. Hal tersebut disebabkan oleh banyak investor yang lebih memilih berinvestasi di deposito karena bunga yang ditawarkan oleh bank lebih tinggi dibandingkan berinvestasi dalam bentuk saham yang beresiko. 
Kemudian sebaliknya pada saat suku bunga BI Rate diturunkan, suku bunga deposito akan ikut turun juga. Sehingga investor akan mencari alternatif yang memberikan hasil investasi lebih tinggi dibandingkan deposito yaitu salah satunya saham. Akibatnya terjadi permintaan yang besar pada saham yang menyebabkan harga saham naik. Naiknya harga saham yang terus meningkat akan meningkatkan pula jumlah return investor berupa capital gain yang cukup menarik bagi investor. Dugaan tersebut menjadi dasar variabel BI Rate menjadi sangat berpengaruh dalam harga saham perusahaan-perusahaan di sektor kimia. Hasil penelitian ini tidak sejalan dengan penelitian yang dilakukan oleh Rohmanda et al, (2014) yang menyatakan bahwa BI rate tidak berpengaruh terhadap harga saham.

\section{Pengaruh Kurs Rupiah/Dolar Terhadap Harga Saham}

Nilai tukar mata uang suatu Negara menjadi acuan perkembangan ekonomi Negara tersebut secara general. Praktik ekonomi terbagi kebanyak bidang seperti bidang pertanian, pariwisata, produksi mesin produksi bahan kimia dan sebagainya. Hal ini dapat dilihat dari kurs rupiah yang merupakan indikator maupun gambaran dari stabilitas perekonomian suatu negara. Jika permintaan kurs rupiah relatif lebih sedikit daripada suplai rupiah maka kurs rupiah ini akan terdepresiasi dan juga sebaliknya. Bagi investor depresiasi rupiah terhadap dollar menandakan bahwa prospek perekonomian Indonesia menurun. Negara dengan stabilitas perekonomian yang bagus biasanya memiliki mata uang yang stabil pula pergerakannya. Negara dengan stabilitas perekonomian yang buruk, mata uangnya cenderung bergerak tidak menentu dan cenderung melemah.

Kemudian dapat disimpulkan bahwa Kurs Rupiah/Dollar terhadap
Harga Saham tidak adanya pengaruh signifikan yang mengindikasikan bahwa besar kecilnya nilai tukar pada tahun 2009-2018 tidak berdampak besar pada naik turunnya harga saham. Sehingga secara praktis mengimplikasikan bahwa pemerintah harus selalu mengambil langkah-langkah strategis untuk memperkuat tingkat Kurs mata uangnya. Sektor kimia merupakan sektor minoritas dimana pelaku usaha ini kurang dari $5 \%$. Dengan 2 hipotesis dasar tersebut yang jika disimpulkan Indonesia kaya akan bahan baku dan kurang pelaku usaha dalam bidang pengolahan kimia serta pasar yg masih terbuka lebar di dalam dan luar negeri maka nilai mata uang tidak terlalu berpengaruh dalam perusahan-perusahaan di sektor kimia. Hasil penelitian ini sejalan dengan penelitian yang dilakukan oleh Ilmi (2017) yang menyatakan bahwa kurs rupiah/dollar tidak berpengaruh terhadap harga saham.

\section{KESIMPULAN DAN SARAN}

\section{Kesimpulan}

Berdasarkan hasil analisis dan pembahasan yang dilakukan, maka dapat disimpulkan sebagai berikut: 1). Price earning ratio, debt to equity ratio, inflasi, BI rate, dan kurs rupiah/dollar secara bersama-sama berpengaruh signifikan terhadap harga saham perusahaan sektor kimia. 2). Price earning ratio secara parsial tidak berpengaruh terhadap harga saham. Hal ini menunjukkan bahwa price earning ratio tidak dapat menjadi tolak ukur investor untuk berinvestasi di pasar saham perusahaan sektor kimia. 3). Debt to equity ratio secara parsial tidak berpengaruh terhadap harga saham. Hal ini menunjukkan bahwa debt to equity ratio tidak dapat menjadi tolak ukur investor untuk berinvestasi di pasar saham perusahaan sektor kimia. 4). Inflasi secara parsial tidak 
berpengaruh terhadap harga saham. Hal ini menunjukkan bahwa inflasi tidak dapat menjadi tolak ukur investor untuk berinvestasi di pasar saham perusahaan sektor kimia. 5). BI rate secara parsial tidak berpengaruh terhadap harga saham. Hal ini menunjukkan bahwa BI rate tidak dapat menjadi tolak ukur investor untuk berinvestasi di pasar saham perusahaan sektor kimia. 6). kurs rupiah/dollar secara parsial tidak berpengaruh terhadap harga saham. Hal ini menunjukkan bahwa kurs rupiah/dollar tidak dapat menjadi tolak ukur investor untuk berinvestasi di pasar saham perusahaan sektor kimia.

Sehingga dapat disimpulkan bahwa secara umum investor yang berinvestasi di saham sektor kimia, lebih banyak investor jangka pendek yang hanya memperhatikan fluktuasi harga saham di pasar.

\section{Saran}

Penelitian ini diharapkan dapat dijadikan bahan pertimbangan bagi para investor maupun calon investor dalam melakukan investasi saham yang tepat dan menguntungkan khususnya untuk saham perusahaan sub sektor kimia. Penelitian ini dapat digunakan sebagai masukan, khususnya keterkaitan fundamental keuangan, teknikal dan fundamental makro ekonomi terhadap kegiatan investasi saham di pasar modal.

Bagi investor yang akan melakukan investasi jangka panjang, sebaiknya selain memperhatikan faktor teknikal juga harus memperhatikan analisis fundamental keuangan, karena fundamental keuangan perusahaan yang baik akan mempengaruhi kelangsungan hidup perusahaan.

Bagi peneliti selanjutnya diharapkan dapat meneliti industri lainnya, dengan periode dan alat ukur yang sama agar dapat diambil kesimpulan umum tentang prilaku investor secara rata-rata di Bursa Efek Indonesia.

\section{DAFTAR PUSTAKA}

Andriyani, Ima dan Armereo, Crystha. 2016. Pengaruh Suku Bunga, Inflasi dan Nilai Buku Terhadap Harga Saham Perusahaan Indeks LQ45 yang Terdaftar di Bursa Efek Indonesia (BEI). Jurnal Ilmiah Orasi Bisnis-Volume 15 Bulan Mei 2016, ISSN: 20851375.hal. 44-64.

Brigham dan Houston. 2010. Dasar-

Dasar Manajemen Keuangan.

(Edisi III). Jakarta: Salemba

Empat.

Darmadji, M. dan M. Fakhrudin. 2011. Pasar Modal Di Indonesia. Jakarta: Salemba Empat.

Harahap, Sofyan Syafri. 2012. Analisis Kritis atas Laporan Keuangan. Jakarta: Rajawali Pers.

Ilmi, Maisaroh Fathul. 2017. Pengaruh Kurs/Nilai Tukar Rupiah, Inflasi dan 1tingkat Suku Bunga SBI Terhadap Indeks Harga Saham Gabungan LQ-45 Periode Tahun 2009-2013. Jurnal Nominal Volume VI Nomor 1 Tahun 2017. Hal: 93108.

Fahmi, Irham. 2015. Pengantar Manajemen Keuangan Teori dan Soal Jawab. Bandung: Alfabeta.

Jogiyanto, 2014. Teori Portofolio dan Analisis Investasi (Edisi ke 10). Yogyakarta: BPFE.

Kasmir. 2012, Analisis Laporan Keuangan. Jakarta: PT. Raja Grafindo Persada.

Kuncoro, Mudrajad. 2007. Manajemen Keuangan Internasional:

Pengantar Ekonomi dan Bisnis Global. Yogyakarta: BPFE:

Munawir, S. 2010. Analisa Laporan Keuangan.Yogyakarta: Liberty.

Nopirin. 2011. Pengantar Ilmu Ekonomi Makro dan Mikro. Yokyakarta: BPFE. 
Pohan, Aulia. 2008. Potret Kebijakan Moneter Indonesia. Jakarta: PT. Raja Grafika Persada.

Ramadhani, Fendi Hudaya dan Pustikaningsih, Adeng. 2017. Pengaruh Debt to Equity Ratio (DER), Return on Equity (ROE), dan Net Profit Margin (NPM) Terhadap Harga Saham Perusahaan Sektor Pertambangan Yang Terdaftar Di Bursa Efek Indonesia Periode 2011-2015. Jurnal Profita Edisi 8 Tahun 2017. Hal. 1-13.

Ratih, Dorothea., Apriatni E.P Dan Saryadi. 2013. Pengaruh EPS, PER, DER, ROE Terhadap Harga Saham Pada Perusahaan Sektor Pertambangan Yang Terdaftar Di Bursa Efek Indonesia (BEI) Tahun 2010-2012. DIPONEGORO JOURNAL OF SOCIAL AND POLITIC Tahun 2013, Hal. 112http://Ejournal-

S1.Undip.Ac.Id/Index.Php/.

Rohmanda, Deny., Suhandak dan Topowijono. 2014. Pengaruh Kurs Rupiah, Inflasi dan BI Rete Terhadap Harga Saham (Studi pada Indeks Sektoral Bursa Efek Indonesia Periode 2005-2013). Jurnal Administrasi Bisnis (JAB) Vol. 13. No. 1 Agustus 2014. Hal. $1-10$.

Rusdin. 2008. Pasar Modal. Cetakan Kedua. Bandung: Alfabeta.
Salvatore, Dominick. 2005. Ekonomi Internasional. Edisi 9. Jakarta: Penerbit Salemba Empat

Sartono, Agus. 2015. Manajemen Keuangan: Teori dan Aplikasi. Edisi Keempat. Yogyakarta: BPFE.

Siamat, Dahlan. 2005. Manajemen Lembaga Keuangan. Jakarta: Lembaga Penerbit Fakultas Ekonomi Universitas Indonesia.

Sugiyono. 2017. Statikstika Untuk Penelitian. Bandung: Alfabeta.

Sukirno, Sadono. 2011. Makro Ekonomi Teori Pengantar. Edisi Ketiga. Jakarta: Rajawali Pers.

Sukwiaty,dkk. 2009. Pengertian Ilmu Ekonomi. Jakarta: Rineka Cipta

Tandelilin, Eduardus.2010. Portofolio dan Investasi Teori dan Aplikasi. Edisi Pertama. Yogyakarta : Kanisius.

Thobarry, Achmad Ath. 2009. Analisis Pengaruh Nilai Tukar, Suku Bunga, Laju Inflasi dan Pertumbuhan GDP Terhadap Indek Harga Saham Sektor Properti Kajian Empiris pada Bursa Efek Indonesia Tahun 2000-2008.

Widoatmodjo, Sawidji. 2012. Cara Sehat Investasi di Pasar Modal. Edisi Revisi. Jakarta: PT. Jurnalindo Aksara Grafika.

Yulianti, Sri Handaru dan Prasetyo, Handoyo. 2002. Dasar-Dasar Manajemen Keuangan, Sekolah Tinggi Ilmu Manajemen YKPN. Yogyakarta. 